medRxiv preprint doi: https://doi.org/10.1101/2021.03.15.21253579; this version posted March 24, 2021. The copyright holder for this preprint (which was not certified by peer review) is the author/funder, who has granted medRxiv a license to display the preprint in It is made available under a CC-BY-ND 4.0 International license.

\title{
Association of NRAMP1-INT4 gene with Susceptibility to Tuberculosis in the Sudanese Population: A Case-Control Study
}

\author{
Authors \\ Sara Gamal Gubara Mohamed ${ }^{1 *}$, Arwa Elaagip ${ }^{2}$, Maryam Atif Salaheldin ${ }^{1}$, Abeer Babiker \\ Idris ${ }^{1}$, Taha Hussein Musa ${ }^{3}$, Fayad Osman Mohammed ${ }^{4}$, Layla Ahmed Mohammed ${ }^{1}$, \\ Hassan Hussein Musa ${ }^{1}$ \\ *Corresponding author: Sj165513@gmail.com \\ ${ }^{1-}$ Department of Medical Microbiology, Faculty of Medical Laboratory Sciences, University \\ of Khartoum, Khartoum, Sudan \\ 2- Department of Parasitology and Medical Entomology, Faculty of Medical Laboratory \\ Sciences, University of Khartoum, Khartoum, Sudan \\ 3- Biomedical Research Institute, Darfur University College, Darfur, Sudan \\ 4- Institute of Endemic Diseases, University of Khartoum, Khartoum, Sudan
}

Email addresses of all authors: SGGM, Sj165513@gmail.com; AE, arwalaagip@yahoo.co.uk; MAS, maryam.atif.se@hotmail.com; ABI, abeer.babiker89@gmail.com; THM, taha.hm99@yahoo.com; FOM, Fayad@iend.org; LAM, Layloosh1@gmail.com; HHM, hassantahir70@hotmail.com. 
medRxiv preprint doi: https://doi.org/10.1101/2021.03.15.21253579; this version posted March 24, 2021. The copyright holder for this

preprint (which was not certified by peer review) is the author/funder, who has granted medRxiv a license to display the preprint in

It is made available under a CC-BY-ND 4.0 International license.

\begin{abstract}
:
Background: Sudan is a Sub-Saharan African country with a high prevalence rate of Tuberculosis. Natural Resistant Associated Macrophage Protein 1 (NRAMP1) plays a potential role in the development of immunity against TB, and it has a critical role in disease resistance. The aim of the study was to evaluate the association of NRAMP1 polymorphism at intron4 (INT4) region with susceptibility to TB infection.
\end{abstract}

Methods: Demographic, clinical and microbiological data were collected from 150 participants and investigated using designed questionnaire. The genotyping of NRAMP1-INT4 polymorphism was performed in 60 TB-infected patients and 50 healthy control using Polymerase chain reaction and restriction fragment-length polymorphism method (PCR-RFLP).

Results: Among cases (60\%) were males, only (3.3\%) were vaccinated. The most reported risk factors were tobacco smoking (17\%), diabetes (10\%), alcohol consumption (2\%) and corticosteroid therapy intakes (1\%). Pulmonary TB was detected in $67 \%$ of the patients, $24 \%$ had pulmonary/MDR and $9 \%$ had extrapulmonary TB. The frequency of wild $G$ allele was significantly higher in cases compared with healthy control subjects (P-value <0.0001). Also, a significant association was observed between the heterozygosity for NRAMP1-INT4 variant and resistance to $\mathrm{TB}$ infection ( $\mathrm{P}$-value 0.001, $\mathrm{OR}=4.83,95 \% \mathrm{CI} 1.96 \sim 11.88$ ). Homozygotes mutant INT4 (C/C) genotype was not detected in both cases and controls. Conclusions: the NRAMP1-INT4 polymorphism may serve as marker of unidentified genetic factors that may play a critical role in host immunity to TB in the Sudanese population. Further studies with large sample size are recommended to determine population-specific genetic associations with TB susceptibility in order to guide TB therapy and prophylaxis in a population-specific manner.

Keywords: $M$. tuberculosis, MDR, NRAMP1, SNP, Sudan. 
medRxiv preprint doi: https://doi.org/10.1101/2021.03.15.21253579; this version posted March 24, 2021. The copyright holder for this preprint (which was not certified by peer review) is the author/funder, who has granted medRxiv a license to display the preprint in

It is made available under a CC-BY-ND 4.0 International license .

\section{Background}

Tuberculosis (TB) is a chronic bacterial disease caused by Mycobacterium tuberculosis (M.tb) which found normally in the environment ${ }^{(1)}$. Transmission of infection occurs via inhalation of droplet nuclei from infected patients during coughing, sneezing or talking and mainly infect lungs ${ }^{(2)}$. It's accounting $2.5 \%$ of global burden diseases with more than $90 \%$ of total cases occurring in developing countries ${ }^{(3,4)}$. In the last report of the World Health Organization (WHO), they estimate that currently about 10 million people developed TB and 1.4 million died in 2019 in which the highest burden is in adult men, who accounted for $56 \%$ of all TB cases, compare to adult women who accounted for $32 \%$ and children for $12 \%$. Among all TB cases, $8.2 \%$ were among people living with HIV ${ }^{(5)}$. African countries contribute $31 \%$ of new cases mostly concentrated in Nigeria and Ethiopia ${ }^{(6,7)}$. Among all cases infected with TB, only 5$10 \%$ will develop active disease during their lifetime, this influenced by several risk factors which directly related to the host such as socioeconomic, behavioral and physiological factors or indirectly associated with susceptibility to infection such as genetic host factors ${ }^{(3,8-10)}$. It's indicated that, $75 \%$ of the patients have more severe form of disease which is exclusive pulmonary involvement $(\mathrm{PTB})^{(11)}$. Extra-pulmonary TB (EPTB) is the occurrence of TB at sites other than lungs. Globally, the prevalence of EPTB among new and relapse TB cases in 2016 was 15\%, the lowest was recorded in western Pacific Region (8\%) while the highest was recorded in the Eastern Mediterranean (24\%) in which $16 \%$ was in African Region ${ }^{(11)}$. Several high-income countries have reported an increased frequency of EPTB over time ${ }^{(11,12)}$.

Sudan is Sub-Saharan African country with population approximately 41 million, ranked at 167 out of 188 countries in the Human Development Index (HDI) with 4.8 million people needing humanitarian assistance because of conflict, environmental and food insecurity factors ${ }^{(13,14)}$. It accounts for $14.6 \%$ of total TB burden in the Eastern Mediterranean region, this percent ranks Sudan among the high prevalence countries ${ }^{(15)}$. In 2017, the estimated TB incident rate in Sudan was 77 per 100.000 individual, with number of 20.438 new and relapse TB cases including HIV co-infected ${ }^{(16)}$ Tuberculosis care and treatment is provided by National Tuberculosis Control Program under the auspices of the Ministry of Health and by several non-governmental organizations (NGOs) who provide care to displaced persons, including those who living in refugee camps ${ }^{(17)}$. There were several National referral centers for tuberculosis 
medRxiv preprint doi: $h t t p s: / / d o i . o r g / 10.1101 / 2021.03 .15 .21253579$; this version posted March 24, 2021. The copyright holder for this preprint (which was not certified by peer review) is the author/funder, who has granted medRxiv a license to display the preprint in It is made available under a CC-BY-ND 4.0 International license .

diagnosis and management in Sudan. Abu Anja Specialized TB hospital is one of those centers located in Omdurman, Khartoum state ${ }^{(18)}$. The diagnostic methods in most of TB centers depends on X-ray imaging, staining by Ziehl- Neelsen Stain and molecular technique of GeneXpert which have been available in 13 states laboratories. As the time of this study, the National reference laboratory located in Khartoum state was the only laboratory with the capacity to perform Mycobacterium drug susceptibility testing $(\mathrm{DST})^{(19)}$.

Several genes were associated with inflammatory and cellular immune response, triggering a protective action against tuberculosis infection ${ }^{(20)}$. Natural Resistant Associated Macrophage Protein 1 (NRAMP1) is a candidate gene, that have been reported in many studies of its critical role in disease resistance in humans, mice's, cattle's and pigs ${ }^{(8,21-25)}$. The human homologues of NRAMPl gene has been cloned and mapped to chromosome $2 \mathrm{q} 35^{(26)}$. It has been thought to be a strong candidate gene for human tuberculosis susceptibility, and several studies were performed to evaluate relationships between $N R A M P 1$ and tuberculosis ${ }^{(26,27)}$. Eleven variants were identified in gene locus as single nucleotide polymorphism (SNP) in certain regions, four of them were found to have a significant genetic association with active tuberculosis infection including; 3'UTR (untranslated region), D543N (G/A: Asparagine/Aspartic acid), 5' promoter (GT)n and INT4 (Intron4: 469+14G/C) ${ }^{(28-30)}$.

Studying the host genetic profile using molecular approaches may help in the understanding of clinical diversity; and improve therapeutics, vaccination global control of tuberculosis infection ${ }^{(31)}$. Many studies have found an association between NRAMP1 gene polymorphisms and the progression of TB to severe forms of pulmonary tuberculosis, rather than susceptibility to M. tuberculosis infection ${ }^{(32)}$. However, to our knowledge, this association has not been studied in the Sudanese population. Thus, the aim of this study was to investigate whether NRAMP1 variant at INT4 region was associated with susceptibility and/or severity of tuberculosis among Sudanese patients using PCR-RFLP method. 
medRxiv preprint doi: $h t t p s: / / d o i . o r g / 10.1101 / 2021.03 .15 .21253579$; this version posted March 24, 2021. The copyright holder for this preprint (which was not certified by peer review) is the author/funder, who has granted medRxiv a license to display the preprint in It is made available under a CC-BY-ND 4.0 International license .

\section{Methods}

\section{Study setting and study population}

The study involved hundred patients with active pulmonary and extra-pulmonary infection, referred to Abu Anja Specialized Tuberculosis Hospital. All patients were ethnically mixed and came from different states in Sudan. Patients with active PTB and PTB/MDR were selected based on abnormal chest X-ray confirmed by results of conventional bacteriological examination including; smear positive for acid fast bacilli (ZN stain) and GeneXpert result for MDR-TB. The EPTB were selected based on bacteriological examination and magnetic resonance imaging (MRI) picture for the extra-pulmonary located infection. For genetic study, fifty control persons were recruited from the Blood Bank Center of Soba Teaching Hospital and selected based on their healthy appearance and no history of TB infection. All subjects in the study were interviewed for collection of data using structured well designed questionnaire and any participant who had chronic illness or one of the risk factors which can effect on the result outcome including those with HIV positive or known to have any autoimmune or chronic inflammatory diseases were excluded. Informed consent was taken from all participants before collecting the blood samples. Approval and clearance for the study was obtained from Abu-Anja Specialized TB Hospital and the research board of the Faculty of Medical Laboratory Sciences, University of Khartoum. $2 \mathrm{ml}$ of venous blood collected in Ethylene-Diaminetetraacetic acid (EDTA) vacutainer were taken to the university laboratory and stored at $-20^{\circ} \mathrm{C}$ for Deoxyribo Nucleic Acid (DNA) extraction for detection of gene polymorphism.

\section{NRAMP1 genotype analysis}

Genomic DNA was extracted from whole blood samples using two types of DNA extraction kits; G-spin ${ }^{\mathrm{TM}}$ Total DNA Extraction Kit and QIAamp DNA Blood Mini Kit in accordance with the manufacturer's recommendation and quality was evaluated using $1 \%$ agarose gel electrophoresis to detect the integrity and sharp bands of DNA. The polymorphic variant (INT4 region) in NRAMP1 gene was studied by PCR-RFLP technique, using sense primer (5'-GTCTGCCATCTCTACTACCCTAAGGTG-3') and antisense primer (5'-CATGTCCCTCTAGGTATGTGCTATCAG-3'). Product size was $510 \mathrm{bp}$. Primer quality was checked by $\mathrm{OLIGO}^{\mathrm{TM}}$ software before use. The iNtRON's Maxime PCR PreMix kit were used for PCR, the tube contains ready mixtures of iTaq ${ }^{\mathrm{TM}}$ DNA polymerase, dNTPs mixture, reaction buffer and gel loading buffer mixed 
medRxiv preprint doi: https://doi.org/10.1101/2021.03.15.21253579; this version posted March 24, 2021. The copyright holder for this preprint (which was not certified by peer review) is the author/funder, who has granted medRxiv a license to display the preprint in

It is made available under a CC-BY-ND 4.0 International license .

with de-ionized water, genomic DNA and primers. PCR amplifying procedure was as follows: 2 min at $95^{\circ} \mathrm{C}, 30$ cycles of $30 \mathrm{sec}$ at $95^{\circ} \mathrm{C}, 30 \mathrm{sec}$ at $65^{\circ} \mathrm{C}, 60 \mathrm{sec}$ at $72^{\circ} \mathrm{C}$ then $5 \mathrm{~min}$ at $72^{\circ} \mathrm{C}$, performed on SENSQUEST lab cycler automated thermal cycler. Product was checked on $1 \%$ agarose gel electrophoresis in SCIE-PLAN (vision machine) and visualize by digital image analysis system for confirmation of the length and integrity of bands. The INT4 region was analyzed for the presence of SNP using PCR product digested with the specific restrictive endonuclease enzyme Apa I (New England Biolabs) reported by Taype et al., $2006^{(33)}$.

\section{Statistical Analysis}

Data were analyzed using statistical package for social science (SPSS statistics 25). We used the unpaired student's t-test (for continuous numerical data) and Chi-square $\left(\mathrm{X}^{2}\right)$ test (for categorical data) ${ }^{(34)}$. Odds Ratio (OR) and 95\% confidence interval (95\%CI) were calculated to quantitatively assess the degree of association between single nucleotide polymorphism (SNP) and tuberculosis infection and between patients and control group. The differences considered statistically significant as P-value $<0.05^{(22)}$.

\section{Results}

\section{Baseline characteristics of the study population}

As illustrated in Table 1., TB infection were mostly reported in males (60\%) with average age of $32.8 \pm 11.83$ years. Collective data were taken from each patient considered the risk factors for developing tuberculosis infection includes; BCG vaccination, tobacco smoking, diabetes, alcohol consumption and corticosteroid therapy. BCG immunization was determined by the presence of a typical scar on either upper arm at the time of blood collection and the result showed that only $3.3 \%$ of the patients have vaccination scar. The most reported risk factors among tuberculosis patients were tobacco smoking (17\%). It was also recorded that $10 \%$ of patients have diabetes mellitus, $2 \%$ consumed alcohol and $1 \%$ received corticosteroid therapy. A total of $67 \%$ patients had pulmonary TB, 24\% diagnosed as pulmonary/MDR-TB and $9 \%$ extra-pulmonary TB (three with extra-thoracic lymphatic, four with bone\& joints and two with stomach TB). Most of TB infected patients were diagnosed by smear positive $\mathrm{ZN}$ stain and chest X-ray findings (83.4\%). All suspected drug resistant MDR cases were diagnosed additionally with GeneXpert (50\%) and the other extra-pulmonary TB suspected patients were diagnosed by MRI (3.3\%). Fifty-eight percent of patients 
medRxiv preprint doi: $h t t p s: / / d o i . o r g / 10.1101 / 2021.03 .15 .21253579$; this version posted March 24, 2021. The copyright holder for this preprint (which was not certified by peer review) is the author/funder, who has granted medRxiv a license to display the preprint in It is made available under a CC-BY-ND 4.0 International license.

whom isolated were classed as new patients start receiving first line anti-tuberculosis drugs in the same month. Of the reminder $20 \%$ have previously complete the first line drugs classed as MDR-TB patients and started treatment with the second line antituberculosis regimens, $17 \%$ were classed as new tuberculosis patients who did not enrolled in the treatment system yet and 5\% had experiences interrupted treatment.

Table 1. Demographic and clinical characteristics of the patients with tuberculosis infection $(n=100)$

\begin{tabular}{rll}
\hline & Variable & Frequency (\%) \\
\hline Gender & Male & $60(60 \%)$ \\
& Female & $40(40 \%)$ \\
& & \\
& $\leq 30$ & $51(51 \%)$ \\
Marital status & $31-40$ & $26(26 \%)$ \\
& $41-50$ & $16(16 \%)$ \\
& Single & $7(7 \%)$ \\
& Married & $58(58 \%)$ \\
Residence & & $42(42 \%)$ \\
& Khartoum & \\
& Omdurman & $22(22 \%)$ \\
& Gazira & $60(60 \%)$ \\
& Nyala & $13(13 \%)$ \\
& White Nile & $1(1 \%)$ \\
& Kordufan & $1(1 \%)$ \\
& Sinnar & $2(2 \%)$ \\
Risk factors & & $1(1 \%)$ \\
& Smoking & \\
& Diabetes & $17(17 \%)$ \\
& Alcohol abuse & $10(10 \%)$ \\
& Corticosteroids therapy & $2(2 \%)$ \\
& & $1(1 \%)$ \\
& Pulmonary TB & $67(67 \%)$ \\
& Pulmonary/MDR & $24(24 \%)$ \\
& Extra-pulmonary & $9(9 \%)$ \\
\hline & &
\end{tabular}

\section{Association of NRAMP1 - INT4 with tuberculosis}

A total of 60 patients were included for the analysis of polymorphic change in the INT4 loci of NRAMP1 and compared with 50 healthy individuals belonging to the same geographical area with no history of previous TB infection. Among the selected cases, 36 were males and 24 were females. The distribution of TB forms was; $50 \%$ pulmonary TB, $36.7 \%$ pulmonary/MDR and $13.3 \%$ were extra-pulmonary TB. The homozygous INT4 (G/G) genotype was identified in $51(85 \%)$ cases with tuberculosis and $27(54 \%)$ 
medRxiv preprint doi: https://doi.org/10.1101/2021.03.15.21253579; this version posted March 24, 2021. The copyright holder for this preprint (which was not certified by peer review) is the author/funder, who has granted medRxiv a license to display the preprint in It is made available under a CC-BY-ND 4.0 International license .

healthy control subjects, while the heterozygous INT4 (G/C) was found in $9(15 \%)$ cases and $23(46 \%)$ healthy controls (P-value 0.001, OR=4.83, 95\%CI 1.96 11.88) (Figure 1). The homozygous INT4 (C/C) genotype was not detected in neither cases nor healthy controls. The frequency of $\mathrm{G}$ allele was significantly higher in cases compared with healthy control subjects (P-value <0.0001). Also, a significant association was observed between the heterozygosity for NRAMPI-INT4 variant and resistance to TB infection (P-value $0.001, \mathrm{OR}=4.83,95 \% \mathrm{CI} 1.96 \sim 11.88$ ) (Table 2).

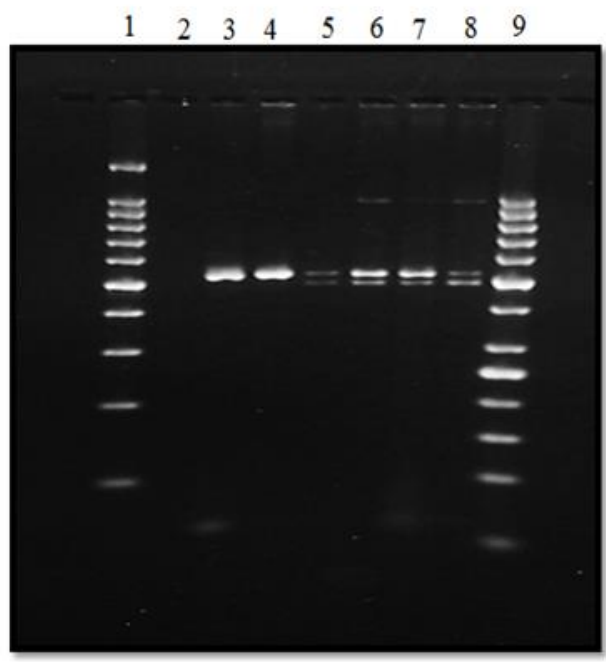

Figure 1: Agarose gel electrophoresis of PCR-RFLP products of cases and healthy controls.

100bp DNA size marker=1; 50bp DNA size marker=9; Negative control= 2; PCR product $=3 ; \mathrm{G} / \mathrm{G}=4 ; \mathrm{G} / \mathrm{C}$ genotype $=5,6,7,8$. 
medRxiv preprint doi: https://doi.org/10.1101/2021.03.15.21253579; this version posted March 24, 2021. The copyright holder for this preprint (which was not certified by peer review) is the author/funder, who has granted medRxiv a license to display the preprint in It is made available under a CC-BY-ND 4.0 International license .

Table 2 Genotypes and Allele Frequency of INT4 Polymorphism in Patients and Healthy Controls

\begin{tabular}{|c|c|c|c|c|}
\hline Polymorphisms & $\begin{array}{l}\text { Patient with } \\
\text { TB n }(\%)\end{array}$ & $\begin{array}{l}\text { Healthy } \\
\text { controls n(\%) }\end{array}$ & P-value & $\begin{array}{l}\text { Odds ratio } \\
\left(95 \% \mathrm{CI}^{*}\right)\end{array}$ \\
\hline \multicolumn{5}{|l|}{ Genotype } \\
\hline G/G & $51(85)$ & $27(54)$ & 0.001 & 1 \\
\hline G/C & $9(15)$ & $23(46)$ & & 4.83 \\
\hline $\mathrm{C} / \mathrm{C}$ & 0 & 0 & & $(1.96 \sim 11.88)$ \\
\hline \multicolumn{5}{|l|}{ Allelic frequency } \\
\hline $\mathbf{G}$ & 0.93 & 0.23 & $<0.0001$ & \\
\hline $\mathbf{C}$ & 0.08 & 0.77 & & \\
\hline
\end{tabular}

$* \mathrm{CI}=$ Confidence Interval

The heterozygous G/C variants were identified in $23.3 \%$ pulmonary $\mathrm{TB}, 4.5 \%$ pulmonary/MDR and $14.3 \%$ extra-pulmonary TB patients. Significant differences were found between patients with pulmonary TB, pulmonary/MDR and healthy controls. However, there were no significant differences or statistical association between G/C genotype and extra-pulmonary TB (P-value 0.074; OR G/C $(95 \% \mathrm{CI})=0.167)($ Table $3)$. 
Table 3 Association between NRAMP1- INT4 polymorphism and clinical forms of tuberculosis

\begin{tabular}{cccccccc}
\hline Genotype & $\begin{array}{c}\text { Control } \\
(\mathrm{n}=50)\end{array}$ & $\begin{array}{c}\text { Pulmonary TB } \\
(\mathrm{n}=30)\end{array}$ & $\begin{array}{c}\text { OR } \\
(95 \% \mathrm{CI})\end{array}$ & $\begin{array}{c}\text { Pulmonary/MDR } \\
(\mathrm{n}=22)\end{array}$ & $\begin{array}{c}\text { OR } \\
(95 \% \mathrm{CI})\end{array}$ & $\begin{array}{c}\text { Extra- } \\
\text { pulmonary TB } \\
(\mathrm{n}=8)\end{array}$ & $\begin{array}{c}\text { OR } \\
(95 \% \mathrm{CI})\end{array}$ \\
\hline $\mathrm{G} / \mathrm{G}$ & $27(54 \%)$ & $23(76.7 \%)$ & 1 & $21(95.5 \%)$ & 1 & $7(87.5 \%)$ \\
$\mathrm{G} / \mathrm{C}$ & $23(46 \%)$ & $7(23.3 \%)$ & $\begin{array}{c}0.357 \\
(0.129-0.983)\end{array}$ & $1(4.5 \%)$ & 0.055 & $1(14.3 \%)$ & 0.167 \\
& & & & $(0.007-0.448)$ & & 0.074 & $(0.19-1.465)$ \\
$\mathrm{P}-\mathrm{value}$ & & 0.042 & & 0.001 & & 3.190 & \\
$\mathrm{X}^{2}$ & & 4.110 & & 11.814 & & \\
\hline
\end{tabular}

\section{Discussion}

Genetic variants in the NRAMPI gene were shown to associate not only with increased susceptibility to TB infection but also with an increased tendency to develop severe outcome ${ }^{(35-37)}$. However, different studies have been published analyzing the contribution of NRAMP1 gene INT4 polymorphism to TB susceptibility and/or severity with conflicting results explained, in part, by ethnic differences. A positive association was observed in West African, American, Asian, Greek and Mestizo Peruvian populations ${ }^{(8,33,34,38)}$, but there was no association in Korean, Moroccan, Iranian, Thai, Taiwanese, Turkish and Indonesian populations ${ }^{(23,39-44)}$. Interestingly, in the present study, we found an association between heterozygosity for NRAMP1-INT4 variant and resistance to TB infection (P-value 0.001, $\mathrm{OR}=4.83,95 \% \mathrm{CI} 1.96 \sim 11.88$ ). This finding is, partially, in agreement with studies conducted in Cambodian and Japanese populations in which an association between heterozygosity for polymorphic NRAMP1 variants (D543N and 3'UTR) and resistance to TB were reported ${ }^{(1,45)}$. The discrepancy between our finding and others could be explained by understanding whether polymeric NRAMP1-INT4 variant itself confers a truly altered susceptibility to TB infection and is functional or the associated allele is in linkage disequilibrium with an unknown disease susceptibility allele. In this regard, Søborg et al. suggested that the NRAMP1 loci (INT4, G543A and 3'UTR) might be markers of unidentified true disease susceptibility loci not present in linkage disequilibrium with the markers in East Africa (46). Therefore, NRAMP1-INT4 polymorphism may, in fact, serve as marker for other genes with a functional impact in ethnic-specific genetic backgrounds. Moreover, the 
medRxiv preprint doi: https://doi.org/10.1101/2021.03.15.21253579; this version posted March 24, 2021. The copyright holder for this preprint (which was not certified by peer review) is the author/funder, who has granted medRxiv a license to display the preprint in

It is made available under a CC-BY-ND 4.0 International license .

unknown cofactors (such as socio-economic factors, nutritional status, or other coinfections) and the complex interactions between gene and other host factors as well as environmental factors might introduce differences and emphasize the difficulties to compare between studies.

Sudan has been estimated to have the highest incidence of $M$. tuberculosis infection in the Eastern Mediterranean region ${ }^{(15)}$. From this view, more insight into the demographic characteristic of the TB patients and exploring the risk factors associated with TB is critical to provide a useful estimate of the potential for development of TB infections then improvement more effective preventive strategies. In this study, TB infection was more detected among males. Similar observation was noticed in other previous studies conducted on Sudanese population shown increased rate of TB infection among males $(17,18,47,48)$. The mean age of our patients is 32.7 -year-old, many studies conducted in Sudan have reported the same results $(18,48,49)$. However, these averages are considered lower when compared to the average mean above 50 which was noticed by other studies in the same area ${ }^{(50,51)}$.

Awareness about the importance of vaccination against TB infection seemed to be very confusing as the BCG scar failure rate was $96.7 \%$. This indicates either those patients are not vaccinated, or the BCG scar disappears. BCG scar is a sensitive indicator of vaccination status up to one year after administration of the vaccine in the first month of life and the scar failure rate was $17 \%$ among Sudanese infants ${ }^{(52)}$. The efficiency of BCG vaccine is very poor in our country. Gorish et al. showed that only $39 \%$ of previously healthy vaccinated adults were positive for Manteaux test, while $61 \%$ were negative and failed to develop induration post tuberculin test, and explained that by either improperly vaccination or invalid vaccine was taken ${ }^{(53)}$. In this study, tobacco smoking was the most reportable risk factor (17\%), followed by diabetes (10\%), alcohol abuse (2\%) and corticosteroid therapy (1\%). Consistent with our result, a study in Spain has shown that tobacco smoking has direct action on the immune system and with alcohol consumption, drug abuse and contact with TB patients considered to be a higher risk factors of pulmonary tuberculosis ${ }^{(54)}$. Ninety-one percent of patients presented with pulmonary $\mathrm{TB}$, while $9 \%$ had extra-pulmonary $\mathrm{TB}$. This was similar to the findings of many studies in which most of patients have pulmonary TB infection. For instance; in Ghana $78.2 \%$ of patients had PTB, while $21.8 \%$ had EPTB ${ }^{(55)}, 70 \%$ had PTB in Spain, while 30\% had EPTB ${ }^{(54)}$, in Europe $80.3 \%$ reported with PTB and $19.3 \%$ 
medRxiv preprint doi: https://doi.org/10.1101/2021.03.15.21253579; this version posted March 24, 2021. The copyright holder for this

preprint (which was not certified by peer review) is the author/funder, who has granted medRxiv a license to display the preprint in

It is made available under a CC-BY-ND 4.0 International license .

had EPTB ${ }^{(56)}$. Tuberculosis of bones and joints (Pott disease) was the most common presentation in EPTB patients. In contrary to a study conducted among the same population that revealed TB lymphadenitis as the most reportable EPTB type ${ }^{(48)}$.

Analysis of tuberculosis drug resistant indicated that, $20 \%$ of previously treated patients have been diagnosed as MDR-TB, which were similar to the prevalence reported in Sudanese studies, $20 \%{ }^{(49)}$ and $22 \%{ }^{(17)}$. Compared with other studies in the region, the prevalence of MDR among previously treated patients double estimate for Ethiopia to the East $(12 \%)^{(57)}$, Kampala to the South $(13 \%){ }^{(58)}$ and less than the prevalence reported from Egypt $(38 \%)^{(57)}$.

\section{Conclusion}

In this study, we found an association between heterozygosity for NRAMP1-INT4 variant and resistance to TB infection. Thus, the NRAMP1-INT4 polymorphism may serve as marker of unidentified genetic factors that may play a critical role in host immunity to TB in the Sudanese population. Further studies with large sample size are recommended to determine population-specific genetic associations with TB susceptibility in order to guide TB therapy and prophylaxis in an population-specific manner.

\section{Abbreviations}

TB: Tuberculosis; NRAMP1: Natural Resistant Associated Macrophage Protein 1; INT4: Intron4; PTB: Pulmonary tuberculosis; EPTB: Extra-pulmonary tuberculosis; HIV: Human immune-deficiency virus; NGOs: Non-governmental Organizations; DST: drug susceptibility testing; SNP: Single nucleotide polymorphism; MDR-TB: Multi-drug resistance tuberculosis; MRI: Magnetic resonance imaging; BCG: Bacillus Calmete- Guérin; ZN: Ziehl- Neelsen Stain; EDTA: Ethylene-Diaminetetraacetic acid; PCR: Polymerase chain reaction; RFLP: Restriction fragment length polymorphism; OD: Odds ration; SPSS: statistical package for social science 
medRxiv preprint doi: https://doi.org/10.1101/2021.03.15.21253579; this version posted March 24, 2021. The copyright holder for this preprint (which was not certified by peer review) is the author/funder, who has granted medRxiv a license to display the preprint in

\section{Acknowledgments:}

The authors are grateful for the patients and healthy controls who volunteer to participate in the study. The authors would like to gratefully acknowledge the assistance of Ahmed Mohamed Mansour in collection of control samples.

\section{Funding}

Not applicable

\section{Availability of data and materials}

The data regarding NRAMP1-INT4 genotypes and alleles distributions among participants are available from the corresponding author on reasonable request.

\section{Authors' contributions}

HHM conceived and supervised the methodology. SGGM, HHM and AE designed the experiments. SGGM, AE, MAS, FOM and LAM performed the experiments. SGGM, THM, AE and ABI analyzed the data. SGGM wrote the manuscript. ABI and AE edited the manuscript. HHM edited and revised the final manuscript. All authors read and approved the final manuscript.

\section{Competing interests}

The authors declare that there are no competing interests

\section{Consent for publication}

Not applicable

\section{Ethics approval and consent to participate}

This study was approved by University of Khartoum, Faculty of Medical Laboratory Sciences review board, and Research Ethics Committee of Abu-Anja Specialized TB Hospital. Informed consent was obtained from all participants before they enrolled in the study. 
medRxiv preprint doi: https://doi.org/10.1101/2021.03.15.21253579; this version posted March 24, 2021. The copyright holder for this preprint (which was not certified by peer review) is the author/funder, who has granted medRxiv a license to display the preprint in

It is made available under a CC-BY-ND 4.0 International license .

\section{References}

1. Delgado JC, Baena A, Thim S, Goldfeld AE. Ethnic-specific genetic associations with pulmonary tuberculosis. The Journal of infectious diseases. 2002;186(10):1463-8.

2. Medapati RV, Suvvari S, Godi S, Gangisetti P. NRAMP1 and VDR gene polymorphisms in susceptibility to pulmonary tuberculosis among Andhra Pradesh population in India: a case-control study. BMC Pulmonary Medicine 2017;17:89.

3. AL-Harbie AM. The Challenges of Tuberculosis Prevention through Early Detection of Latent Tuberculosis Infection in New Immigrants to the State of Kuwait: University of Edinburgh; 2012.

4. Pushpo TA. A Study on Knowledge \& Awarness of Tuberculosis Among Unedrgraduate Students of Private Universities in Dhaka East West University; 2013.

5. WHO. Global Tuberculosis Report 2020. 2020.

6. Hasbelrasoul Ali R, Yousif Ibrahim N, Elegail A, Abdelrhman Mohamed Eltohami N, Ebraheem R, Faroug Mohammed Ahmed S, et al. Evaluation of GeneXpert MTB/RIF and line probe assay for rapid diagnosis of Mycobacterium tuberculosis in Sudanese pulmonary TB patients2017. 426-9 p.

7. Farzianpour F, Kooshad MA. Study of The Status of Tuberculosis Control Program Based on The Impiementation of The Directly Observed Treatment ShortCourse Strategy (DOTS). Materia socio-medica. 2016;28(4):249-52.

8. Yuan L, Ke Z, Guo Y, Xi X, Luo Z. NRAMP1 D543N and INT4 polymorphisms in susceptibility to pulmonary tuberculosis: A meta-analysis. Infection, genetics and evolution : journal of molecular epidemiology and evolutionary genetics in infectious diseases. $\vee-0 \leqslant: 91 ; r \cdot 1 \vee$.

9. Narasimhan P, Wood J, Macintyre CR, Mathai D. Risk factors for tuberculosis. Pulmonary medicine. 2013;2013:828939.-

10. Sobota RS. Genetice of Tuberculosis Resistance: Vanderbilt University; 2015. 11. Sotgiu G, Falzon D, Hollo V, Ködmön C, Lefebvre N, Dadu A, et al. Determinants of site of tuberculosis disease: An analysis of European surveillance data from 2003 to 2014. PloS one. 2017;12(11):e0186499-e.

12. WHO. Global tuberculosis report 2016 Switzerland: World Health Organization; $201 \quad$ I $\quad$ r $\quad$ p]. Available from: http://www.who.int/iris/handle/10665/250441.

13. Organization WH. Global tuberculosis report 2017 [updated 3/24]. Available from: https://apps.who.int/iris/handle/10665/259366.

14. Hassanain SA, Edwards JK, Venables E, Ali E, Adam K, Hussien H, et al. Conflict and tuberculosis in Sudan: a 10-year review of the National Tuberculosis Programme, 2004-2014. Conflict and Health. 2018;12(1):18.

15. Khalid FA, Hamid ZA, Mukhtar MM. Tuberculosis drug resistance isolates from pulmonary tuberculosis patients, Kassala State, Sudan. International journal of mycobacteriology. 2015;4(1):44-7.

16. Elduma AH, Mansournia MA, Foroushani AR, Ali HMH, Salam Elegail AMA, Asma Elsony A, et al. Assessment of the risk factors associated with multidrug resistance tuberculosis in Sudan: a case control study. Epidemiology and health. 2019:e2019014.

17. Sharaf Eldin GS, Fadl-Elmula I, Ali MS, Ali AB, Salih ALG, Mallard K, et al. Tuberculosis in Sudan: a study of Mycobacterium tuberculosis strain genotype and susceptibility to anti-tuberculosis drugs. BMC Infectious Diseases. 2011;11(1):219. 
medRxiv preprint doi: https://doi.org/10.1101/2021.03.15.21253579; this version posted March 24, 2021. The copyright holder for this preprint (which was not certified by peer review) is the author/funder, who has granted medRxiv a license to display the preprint in

It is made available under a CC-BY-ND 4.0 International license .

18. Adam MA, Hamdan Mustafa Hamdan. Khalil, Eltahir Awad Gasim. Initial second-line drug resistance of Mycobacterium tuberculosis isolates from Sudanese retreatment-patients. Journal of Clinical Tuberculosis and Other Mycobacterial Diseases. 2017;9:21-3.

19. Elegail A, Ibrahim Mohamed NY, Mohamed Nour EO, Hoffner S, Haile M. Molecular characterization of Mycobacterium tuberculosis isolates from pulmonary tuberculosis patients in Khartoum, Sudan. International journal of mycobacteriology. 2018;7(3):236-41.

20. Pacheco AG, Moraes MO. Genetic polymorphisms of infectious diseases in case-control studies. Disease markers. 2009;27(3):173-86.

21. Wu L, Deng H, Zheng Y, Mansjo M, Zheng X, Hu Y, et al. An association study of NRAMP1, VDR, MBL and their interaction with the susceptibility to tuberculosis in a Chinese population. International journal of infectious diseases : IJID : official publication of the International Society for Infectious Diseases. 2015;38:129-35.

22. Wu F, Zhang W, Zhang L, Wu J, Li C, Meng X, et al. NRAMP1, VDR, HLADRB1, and HLA-DQB1 gene polymorphisms in susceptibility to tuberculosis among the Chinese Kazakh population: a case-control study. BioMed research international. 2013;2013:484535.

23. Vejbaesya S, Chierakul N, Luangtrakool P, Sermduangprateep C. NRAMP1 and TNF-alpha polymorphisms and susceptibility to tuberculosis in Thais. Respirology. 2007;12(2):202-6.

24. Takahashi K, Hasegawa Y, Abe T, Yamamoto T, Nakashima K, Imaizumi K, et al. SLC11A1 (formerly NRAMP1) polymorphisms associated with multidrugresistant tuberculosis. Tuberculosis. 2008;88(1):52-7.

25. Liu K, Zhang B, Teng Z, Wang Y, Dong G, Xu C, et al. Association between SLC11A1 (NRAMP1 (polymorphisms and susceptibility to tuberculosis in Chinese Holstein cattle. Tuberculosis. 2017;103:10-5.

26. Abe TI, Y. Ando, M. Yokoyama, T. Yamamoto, T. Nakashima, K. Takagi, N. Baba, H. Hasegawa, Y. Shimokata, K. NRAMP1 polymorphisms, susceptibility and clinical features of tuberculosis. The Journal of infection. 2003;46(4):215-20.

27. Greenwood CM, Fujiwara TM, Boothroyd LJ, Miller MA, Frappier D, Fanning EA, et al. Linkage of tuberculosis to chromosome 2q35 loci, including NRAMP1, in a large aboriginal Canadian family. American journal of human genetics. 2000;67(2):405-16.

28. Gao PS, Fujishima S, Mao XQ, Remus N, Kanda M, Enomoto T, et al. Genetic variants of NRAMP1 and active tuberculosis in Japanese populations. International Tuberculosis Genetics Team. Clinical genetics. 2000;58(1):74-6.

29. Li X, Yang Y, Zhou F, Zhang Y, Lu H, Jin Q, et al. SLC11A1 (NRAMP1) polymorphisms and tuberculosis susceptibility: updated systematic review and metaanalysis. PloS one. 2011;6(1):e15831.

30. Larcombe LA ,Mookherjee N, Lodge AM. Frequency of NRAMP1 Gene Polymorphisms among Canadian First Nations Peoples Experiencing Endemic Tuberculosis. Mycobacterial Diseases. 2015;05(05.(

31. Awomoyi AA, Marchant A, Howson JM, McAdam KP, Blackwell JM, Newport MJ. Interleukin-10, polymorphism in SLC11A1 (formerly NRAMP1), and susceptibility to tuberculosis. The Journal of infectious diseases. 2002;186(12):180814.

32. Zhang W, Shao L, Weng X, Hu Z, Jin A, Chen S, et al. Variants of the natural resistance-associated macrophage protein 1 gene (NRAMP1) are associated with severe 
medRxiv preprint doi: https://doi.org/10.1101/2021.03.15.21253579; this version posted March 24, 2021. The copyright holder for this preprint (which was not certified by peer review) is the author/funder, who has granted medRxiv a license to display the preprint in

It is made available under a CC-BY-ND 4.0 International license .

forms of pulmonary tuberculosis. Clinical infectious diseases : an official publication of the Infectious Diseases Society of America. 2005;40(9):1232-6.

33. Taype CA, Castro JC, Accinelli RA, Herrera-Velit P, Shaw MA, Espinoza JR. Association between SLC11A1 polymorphisms and susceptibility to different clinical forms of tuberculosis in the Peruvian population. Infection, genetics and evolution : journal of molecular epidemiology and evolutionary genetics in infectious diseases. 2006;6(5):361-7.

34. Stagas MK, Papaetis GS, Orphanidou D, Kostopoulos C, Syriou S, Reczko M, et al. Polymorphisms of the NRAMP1 gene: distribution and susceptibility to the development of pulmonary tuberculosis in the Greek population. Medical science monitor : international medical journal of experimental and clinical research. 2011;17(1):PH1-6.

35. Bellamy R. NRAMP1 and susceptibility to tuberculosis. The international journal of tuberculosis and lung disease : the official journal of the International Union against Tuberculosis and Lung Disease. 2002;6(9):747.

36. Hoal EG, Lewis LA, Jamieson SE, Tanzer F, Rossouw M, Victor T, et al. SLC11A1 (NRAMP1) but not SLC11A2 (NRAMP2) polymorphisms are associated with susceptibility to tuberculosis in a high-incidence community in South Africa. The international journal of tuberculosis and lung disease : the official journal of the International Union against Tuberculosis and Lung Disease. 2004;8(12):1464-71.

37. Ben-Selma W, Harizi H, Letaief M, Boukadida J. Age- and gender-specific effects on NRAMP1 gene polymorphisms and risk of the development of active tuberculosis in Tunisian populations. International journal of infectious diseases : IJID : official publication of the International Society for Infectious Diseases. 2012;16(7):e543-50.

38. Bellamy R, Ruwende C, Corrah T, McAdam KP, Whittle HC, Hill AV. Variations in the NRAMP1 gene and susceptibility to tuberculosis in West Africans. The New England journal of medicine. 1998;3. $\left\{-7 \varepsilon \cdot:(1 \cdot)^{r} \wedge\right.$

39. Ryu S, Park YK, Bai GH, Kim SJ, Park SN, Kang S. 3'UTR polymorphisms in the NRAMP1 gene are associated with susceptibility to tuberculosis in Koreans. The international journal of tuberculosis and lung disease : the official journal of the International Union against Tuberculosis and Lung Disease. 2000;4(6):577-80.

40. El Baghdadi J, Remus N, Benslimane A, El Annaz H, Chentoufi M, Abel L, et al. Variants of the human NRAMP1 gene and susceptibility to tuberculosis in Morocco. The international journal of tuberculosis and lung disease : the official journal of the International Union against Tuberculosis and Lung Disease. 2003;7(6):599-602.

41. Jafari M, Nasiri MR, Sanaei R, Anoosheh S, Farnia P, Sepanjnia A, et al. The NRAMP1, VDR, TNF-alpha, ICAM1, TLR2 and TLR4 gene polymorphisms in Iranian patients with pulmonary tuberculosis: A case-control study. Infection, genetics and evolution : journal of molecular epidemiology and evolutionary genetics in infectious diseases. 2016;39:92-8.

42. Liaw YS, Tsai-Wu JJ, Wu CH, Hung CC, Lee CN, Yang PC, et al. Variations in the NRAMP1 gene and susceptibility of tuberculosis in Taiwanese. The international journal of tuberculosis and lung disease : the official journal of the International Union against Tuberculosis and Lung Disease. 2002;6(5):454-60.

43. Solgun HA, Tastemir D, Aksaray N, Inan I, Demirhan O. Polymorphisms in NRAMP1 and MBL2 genes and their relations with tuberculosis in Turkish children. Tuberkuloz ve toraks. 2011;59(1):48-53.

44. Sahiratmadja E, Wieringa FT, van Crevel R, de Visser AW, Adnan I, Alisjahbana B, et al. Iron deficiency and NRAMP1 polymorphisms (INT4, D543N and 
3'UTR) do not contribute to severity of anaemia in tuberculosis in the Indonesian population. The British journal of nutrition. 2007;98(4):684-90.

45. Gao P, Fujishima S, Mao X. Genetic variants of NRAMP1 and active tuberculosis in Japanese populations. International Tuberculosis Genetics Team Clin Genet. 2000;58:74-6.

46. Søborg C, Andersen AB, Range N, Malenganisho W, Friis H, Magnussen P, et al. Influence of candidate susceptibility genes on tuberculosis in a high endemic region. Molecular Immunology 2007;44 2213-20.

47. Ali AOA, Prins MH. Disease and treatment-related factors associated with tuberculosis treatment default in Khartoum State, Sudan: a case-control study. Eastern Mediterranean health journal $=\mathrm{La}$ revue de sante de la Mediterranee orientale $=$ al Majallah al-sihhiyah li-sharq al-mutawassit. 2017;23(6):408-14.

48. Banaga A, Siddiq N, Alsayed R, Babiker R, Elmusharaf K. Prevalence and presentation of tuberculosis among hemodialysis patients in Khartoum, Sudan. Saudi Journal of Kidney Diseases and Transplantation. 2016;27(5):992-6.

49. Sabeel SM, Salih MA, Ali M, El-Zaki SE, Abuzeid N, Elgadi ZA, et al . Phenotypic and Genotypic Analysis of Multidrug-Resistant Mycobacterium tuberculosis Isolates from Sudanese Patients. Tuberculosis research and treatment. 2017;2017:8340746.

50. Ates G, Yildiz T, Danis R, Akyildiz L, Erturk B, Beyazit H, et al. Incidence of tuberculosis disease and latent tuberculosis infection in patients with end stage renal disease in an endemic region. Renal failure. 2010;32(1):91-5.

51. Malik GH, Al-Harbi AS, Al-Mohaya S, Al-Khawajah H, Kechrid M, Al Hassan $\mathrm{AO}$, et al. Eleven years of experience with dialysis associated tuberculosis. Clinical nephrology. 2002;58(5):356-62.

52. Kheir AE, Alhaj AA, Ibrahim SA. The sensitivity of BCG scar as an indicator of previous vaccination among Sudanese infants. Vaccine. 2011;29(46):8189-91.

53. Gorish B. screening-of-bcg-vaccine-efficacy-among-healthy-vaccinatedadults-in khartoum-Sudan 20182018. 2-5 p.

54. Arnedo-Pena A, Romeu-Garcia MA, Meseguer-Ferrer N, Vivas-Fornas I, Vizcaino-Batlles A, Safont-Adsuara L, et al. Pulmonary Versus Extrapulmonary Tuberculosis Associated Factors: A Case-Case Study. Microbiology insights. 2019; $12: 1178636119840362$.

55. Ohene SA, Bakker MI, Ojo J, Toonstra A, Awudi D, Klatser P. Extrapulmonary tuberculosis: A retrospective study of patients in Accra, Ghana. PloS one . (1) $) \leqslant ; .+19 \mathrm{e} 0209650$.

56. Sandgren A, Hollo V, van der Werf MJ. Extrapulmonary tuberculosis in the European Union and European Economic Area, 2002 to 2011. Euro Surveill. 2013;18(12.(

57. WHO. Policy guidance on drug susceptibility testing (DST) of second-line antituberculosis drugs World Health Organization; 2008. Available from: http://whqlibdoc.who.int/hq/2008/WHO_HTM_TB_2008.392_eng.pdf.

58. Temple B, Ayakaka I, Ogwang S, Nabanjja H, Kayes S, Nakubulwa S, et al. Rate and amplification of drug resistance among previously-treated patients with tuberculosis in Kampala, Uganda. Clinical infectious diseases : an official publication of the Infectious Diseases Society of America. 2008;47(9):1126-34. 